Journal of Business and Tourism

Volume 05 Number 02

July-December, 2019

\title{
Impact of Technology Readiness on User Satisfaction: Evidence Customer Intention to Use Mobile Banking in Punjab
}

\author{
Maham Aslam \\ Department of Commerce, Bahauddin Zakariya University Multan \\ Mahamaslam225@gmail.com \\ Shakeel Ahmed \\ Department of Commerce, Bahauddin Zakariya University Multan \\ Ahmedshakeel502@gmail.com \\ Hafiz Muhammad Sajjad \\ Comsats University Islamabad, Vehari Campus \\ Hafizsajjad1419@gmail.com
}

\begin{abstract}
Technology advancement in the payment systems have led to more noteworthy access to formal financial framework.The desire of this study is to contemplate the factors that impact the intention to utilize mobile banking in Pakistan with view of using technology readiness acceptance model (TRAM). This study tests how the antecedents of technology readiness affect the intention to use mobile banking. The hypothetical model of this study is the blend of technology readiness (TR) and technology acceptance model (TAM), while the mediating role of user satisfaction fully mediates, that when the user perceives easy to use the technology due to effect of technology readiness to the adopting mobile banking. This study collected data from five commercial bank of Punjab such as Askari Bank, Allied bank, United bank, Bank Alfalah, Muslim commercial bank, Standard chartered bank and there are 450 responded as the utilization of mobile banking is sufficient, advance and time saving technology. However, it is accomplishing with the help of model. The discussion on the results of hypothesis testing and the conclusion both are presenting as associated section of the study.
\end{abstract}

Keywords: Technological Advancement, Technology Readiness, User Satisfaction, Customer Intention

\section{Introduction}

Mobile banking is renowned as financial organizations have relied on that innovation since from last ten years. This big revolution in banking sector is originate due to the technology progression. The advancement of technology, especially in the mobile phone has provided windows of opportunities for the financial institutions to bring out new financial products and services to meet up the prospect. Mobile banking is viewed as a part of automatic banking with consumers connecting to their bank via a mobile gadget such as cell phone. Drexelius and Herzig (2001) also defines it as the platform to perform transactions via an electronic device, or to carry out business transactions via a portable station. Banks should give the awareness of mobile banking through the online demonstration and mass media (Sindhu, 2018).To enjoy such access, 
the user, first, needs to install the application of mobile banking on the user's SIM card. This application will create significant value by enabling users to obtain prompt and interactive banking services entirely at their fingertips (Mallat et al., 2004). This innovation allows customers to switch from traditional counter to digital where clients can perform their business transaction twenty-four hours daily by only using their smartphones or tablets. Banking is becoming dominated by tech-savvy mobile technology in use by customers. Banks are finding themselves at different stages of preparedness for a potential new way of interacting with their customers. Based on Barquin and Vinayak (2015), about $40 \%$ of upscale customers in the Asia prefer mobile banking or online banking. This indicates the variation of customer's preference in the market when the usage of bank branch services throughout Asia has drop by 27\% since 2007. In conjunction with that, Barquin \& Vinayak (2015) predicted that the number of digital banking for ASEAN and Australia will rise up from 60 million in 2012 to 150 million in 2020.

\section{Significance of the Study}

Mobile banking is comparatively new in Pakistan compared to use of internet banking, thus leaving lots of room for development. As at 2015, Pakistan had 114.66 million mobile subscribers, which accounted for just $32.0 \%$ of population to mobile banking subscribers. Therefore, it is essential to know the amount of mobile banking acceptance by consumers as well as to study the factors affecting intentions to practice it for financial transactions (Shankar \& Kumari, 2016).Pakistan's financial numbers still not good when compared to global standards. For example, In South Asia, Pakistan ranks lowest, only $13 \%$ of adults having bank accounts relative to Sri Lanka 83\%, India 53\% and Bangladesh 31\% (Rizvi et al., 2017). At an international level, financial inclusion is also little when compared to Africa 34\%, Latin America and the Caribbean 51\% and overall in developing countries 51\% (Khan \& Rashid, 2015).

Furthermore, Pakistan downs below the global gender gap with many women are financially excluded than men. The difference is also shown between rural and urban inhabitants and their true access to basic financial services. Mobile banking enabled banks to lower its expenditure by having the customer to interact with electronic banking facilities rather than with a teller (Mishkin and Eakins, 2008), which indirectly reduce the human resources cost. Not only mobile banking reduces bank's operating cost, but it also offers the banks with analytical data of consumer pattern of purchases, their interest, and habit (Chowdhary, 2017). It is vital for banks to assess whether they have the system needed to be mobile banking ready so that the banks can find areas of perfections in their operation (Ramaseshan, Kingshott \& Stein, 2015). Mobile banking is proven to offer an advantage to the customers in improving and upgrading their lifestyle, but why are there still consumers that are reluctant to adopt mobile banking. Therefore, the findings presented in this paper can be used by both practitioners and researchers to evaluate the readiness and adoption level of customers in banks and come up with the right solution to better services of mobile banking and increase its usage rate (Sharma, 2015). Finally, pleasing customers would be the important success factor for digital banking. In line with that, this research study intends to provide insight into the factors and their link with customers to promote and practice mobile banking particularly in banks of Lahore.

\section{Literature Review}

Technology readiness measures the adaption and reaction of people towards new ideas introduce in their routine life. It suggested that the adoption phase of new technologies, customers develop optimistic or negative moods regarding that product (Başgöze, 2015). These feeling indirectly acts as an indication of the customer's readiness level in adopting new technology. 
As per Green and Johnson (2015), there are couple of basic segments of innovation status that should be considered by the specialists and experts which incorporate innovation preparation that is not the same as one individual to another and regarded to be multifaceted where different sorts of convictions blend to deliver one's general TR. Other than that, innovation status can likewise be utilized to foresee and clarify buyer conduct towards new innovation

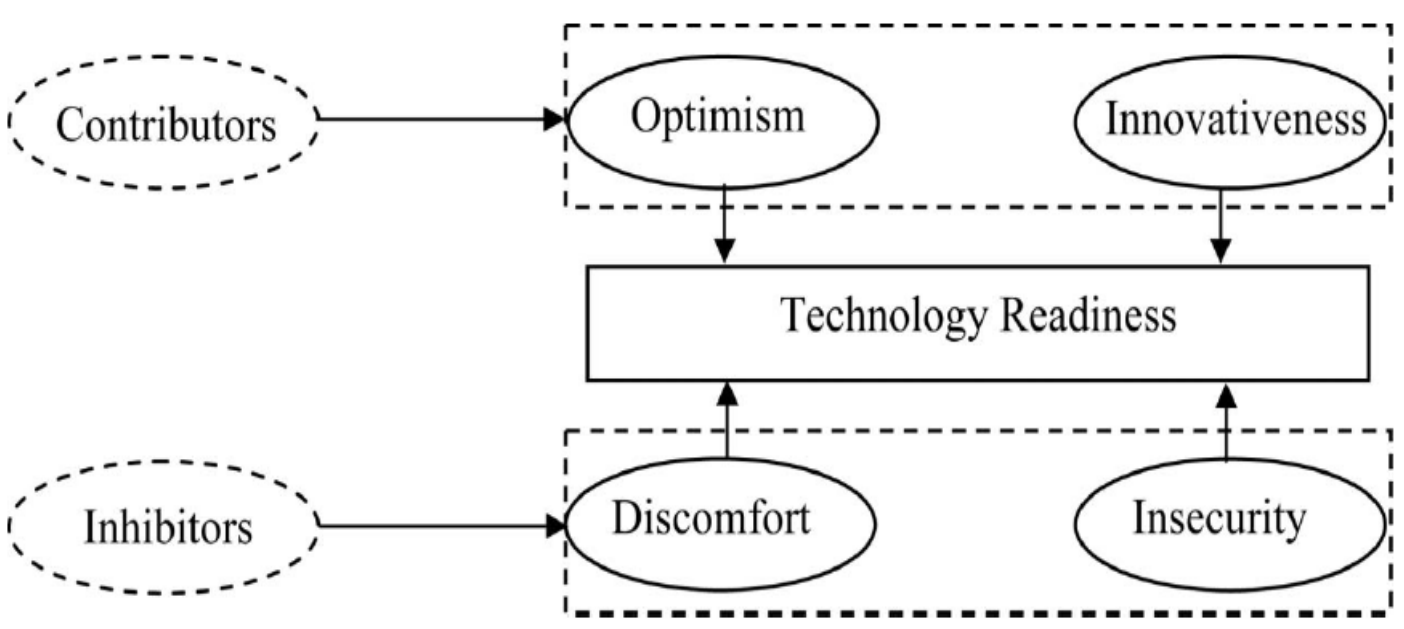

Fig 1.1: technology readiness drivers, Parasuraman and Colby (2001)

Optimism and innovativeness are dynamic drivers of TR, which urge people to utilize new innovative item and administrations. These impact buyers to hold an uplifting demeanor toward innovation. Then again, inconvenience and weakness are the negative drivers in the innovation status build. As per Yen (2005), these drivers make clients hesitant and bring down the goal to decide on new innovation. Every one of the four drivers in the TR build are generally autonomous of one another with every characteristic demonstrative of individual receptiveness towards new innovation (Öfjäll et al., 2016). The connection between TR and their affinity to utilize innovation is exactly affirmed by Parasuraman (2000). A man's inclination to utilize new innovations, as communicated in the technology readiness status build, can be thought of as a perspective coming about because of a gestalt of mental empowering influences and inhibitors (Demirci \& Ersoy, 2008). As supported by Yen (2005) that not all buyers are similarly prepared to grasp new innovation. In addition, likewise concurred that client with various technology readiness profiles differentiate fundamentally in regards to Internet-related practices. The two sorts of research done by Lin and Chang (2011) concurred that technology readiness can't be overlooked in evaluating the selection dimension of clients particularly with regards to selfbenefit innovation. Accordingly, the job of technology preparation ought to be incorporated into any of technology acknowledgment display (Lin \& Hsieh, 2012; Verhoef et al., 2009).

Technology Readiness Index (TRI) that was refined by Parasuraman and Rockbridge Associates, Inc in 1999 fills in as a comprehension of client's inspirations and restraints in respects of the selection of revolutionized service delivery in. Innovation preparation record is a scale to gauge person's dimension of status in utilizing innovation. TRI is keen on the inclination of utilizing innovation, rather than the capability to utilize it (Demirci \& Ersoy, 2008). The pace of 
technological change has quickened, with the assistance of fast Internet get to, portable trade, online networking, and distributed computing. In this manner, the significance and functional importance of the Technology Readiness (TR) develop will keep on developing, equivalent with quickly advancing advances. Optimism and innovativeness are two empowering agents of innovation status (Godoe \& Johansen, 2012). As per Chen, Chen and Chen (2009), Optimism thinking is distinguished as a critical motivator of social expectation towards the persistent utilization of SST services. The higher optimism of clients had, the higher the fulfillment and continuation aims of SSTs that are created. Therefore, a man with good faith and ingenuity and little discomfort and insecurity are bound to utilize new innovation. Actuality, customers who are low on imaginative convictions may require more direction and help with rehearsing the innovation. It is recommended that imaginativeness is more firmly identified with seen handiness instead of saw convenience as a shopper with high ingenuity level will make sense of the innovation themselves (Guhr et al., 2013).Besides, look into research has revealed a positive connection between technology readiness and perceived helpfulness (Fang et al., 2016). Research found that there is a constructive connection between client innovativeness and individuals' attitudes toward utilizing the services (Lam et al., 2016).

Moreover, purchasers who exceedingly score on the uneasiness scale trust that their insight into technology isn't adequate, in this way, cause them to feel discouraged (Spencer, 2011); particularly when shopper confronting mechanical item, individual with abnormal state of inconvenience may end up upset for not having adequate master encountering on the technology. Hence, they may trust that the tech-item was not intended for them and abstain from attempting the item. In addition, inconvenience can make the customer have a general neurosis towards technology. The two inhibitors of technology preparation are discomfort and insecurity. These inhibitors represent negative dispositions toward new innovation (Demirci \& Ersoy, 2008). Lam et al. (2008) find that discomfort adverse effects the period of time for a consumer to acknowledge the web and usability of the web. Moreover, the research aftereffects likewise discovered that inconvenience gives a barely negative impact on perceived handiness (Walczuch et al., 2007).Discomfort's dimension is to some degree more across the board among females and more seasoned shoppers contrasted with male and youthful buyers. As indicated by Naumanen (2006) more females (51\%) than guys (38\%) trust that innovation is regularly too muddled to ever be helpful. Though, with regards to age, the shopper with the age 65 years or more additionally find that technology is difficult to receive contrasted with those under 30 years old. In this manner, reflecting the age distinction and sexual orientation, distress level scored low among male and youthful shoppers.

Security has been one of the vital issues in online business and versatile monetary services which influence client to see that mobile payment process could be a high risk (Merritt, 2011). A study built up that some conspicuous hindrances of technology acknowledgment were because of security and protection concerns (Lin et al., 2007). High close to home insecurity and inconvenience with innovation lead to bring down apparent convenience of an explicit innovation. Besides, insecurity is likewise reflected by a high level of worry with giving out charge card number over PCs and managing organizations open just on the web. Despite the fact that individuals' innovation related insecurity are most articulated for the online exchange, they are in no way, shape or form constrained to web based business. 


\section{Research Framework}

The intention to use mobile banking is constructed in the model as dependent variable (Wang et al., 2006), whereas the other four technology readiness driver were independent variables (optimism, innovativeness, discomfort and insecurity) adapted from Parasuraman and Colby (2014). In the interim, mediator factor was adopted from (David, 1989). Because of the frail correlation of ease of use with user satisfaction, this examination just means to consider the relationship of user satisfaction towards the client's need to utilize mobile banking.

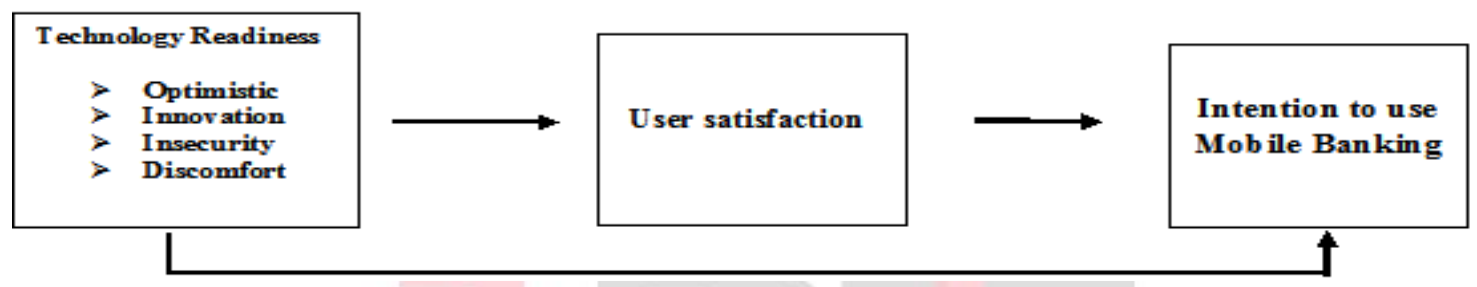

Figure 1.2: Proposed Research model

\section{Hypotheses Development}

On the basis of framework in Figure 1.2, the following hypotheses were developed.

$\mathrm{H}_{1}$ : There is positive relationship between optimism and user satisfaction.

$\mathrm{H}_{2}$ : There is positive relationship between Innovativeness and user satisfaction.

$\mathrm{H}_{3}$ : There is negative relationship of discomfort with user satisfaction.

$\mathrm{H}_{4}$ : There is negative relationship of insecurity with user satisfaction.

$\mathrm{H}_{5}$ : The relationship between optimism, innovativeness, discomfort, insecurity and intention to use mobile banking which is mediated by user satisfaction.

\section{Research Methodology}

The information gathered from the survey would be examined utilizing SPSS 24.0. The analysis of the data in this segment was done sequentially. The statistic information of the respondents was the first to be interpreted. At that point, reliability test, descriptive analysis, and correlation, then in the last regression analysis was performed. Additionally, hypotheses of this study were inspected to guarantee whether the findings assert them or not. The discoveries of the analyzed information would decide the result because of technology readiness on intention to use mobile banking with mediation of user satisfaction.

\section{Sampling}

As the investigation concerned with the opinion of clients who are the user of mobile banking. Notwithstanding, the popularity of that service in Pakistan increased and it identified through this study applied on some big banks such as Askari bank, Bank Alfalah, United bank, Muslim commercial bank, standard chartered bank. Firstly, it has taken the response from the user of mobile banking than it was mandatory to have some investigation from the bank's employees because they provide services to the clients. Moreover, the staff have more learning as they presented the mobile banking service so it has taken some information from bank staff as well. 


\section{Sample Size}

In the first place, it is on the grounds that the bank workers are simply the bank client. A populace is portrayed by Sekaran and Baugie (2013) as the whole gathering of individuals, occasions or things of attention that the scholars desire to think about. The study was directed among the banks' employees in area Punjab, and 450 questionnaires flowed to the respondents. At that point, cleaning and preparation of information started after the returned surveys by the members.Add up to 450 polls were scattered. Just 430 surveys were returned. These returned polls no one but 410 can be utilized and other 40 surveys were not filled appropriately and disposed of from the pool of the returned surveys. The quantity of population in this research is 410 staff $(\mathrm{N}=410)$. By mentioning to Krejcie and Morgan (1970) technique, this examination chose to utilize a base sample size of 410 .

\begin{tabular}{lll}
\hline Respondents & Frequency & Percentage (\%) \\
\hline Distributed questionnaires & 450 & $100 \%$ \\
Reverted & 430 & $95.55 \%$ \\
Excluded & 20 & $4.44 \%$ \\
Acceptable questionnaires & 410 & $91.11 \%$ \\
\hline
\end{tabular}

\section{Table 1.1: Response rate and Frequency}

Respondents' Profile

This research has demographic variables consisted of job position, marital status, educational background, they are explained in the below table 1.2.

\begin{tabular}{lllc}
\hline & Categories & Frequency & $(\%)$ \\
\hline Job Position & Junior staff & 118 & 28.78 \\
& Senior staff & 292 & 71.21 \\
& & & \\
\hline Marital Status & Married & 211 & 51.46 \\
& Unmarried & 173 & 42.19
\end{tabular}

Others

\begin{tabular}{llll} 
& 26 & 6.34 \\
\hline $\begin{array}{l}\text { Educational } \\
\text { background }\end{array}$ & Bachelor & 222 & 54.14 \\
& MS/Mphil & 76 & 18.53
\end{tabular}

Others

\section{Table 1.2: Participants' trend}

It was demonstrated that the senior staffs among the respondents were $71.21 \%$ while the junior staffs were $28.78 \%$. This uncovers more than $33 \%$ of the tested respondents were senior staff in their different spots of works who are using this mobile banking service. Likewise, it demonstrates that $63 \%$ of the respondents were changeless staff while the impermanent staffs were $33 \%$. This shows greater part of the respondents were permanent employees in their 
different working environments. Furthermore, among lesser staff most of them were new employees' and it shows their less time to start banking application. Regarding the respondents' dimension of education, the table indicated that $18.53 \%$ held MS/MPhil degrees while $27.31 \%$ have packed away degree in different fields of study, 54.14\% held bachelor degree declarations. This uncovers major share of the employee's regular workers in banks were holding bachelor or undergraduate degrees. Highest share of the respondents was married people as their rate was $51.46 \%$, others are either unmarried or separated/isolated or widows. The table further shows that unmarried $42.19 \%$ among them others belong to $6.34 \%$. From the above descriptive investigation, it is detectable that $28 \%$ of the respondents were junior, while $71 \%$ were seniors. Married among them were $51 \%$. Those that have more education were $54 \%$. This demonstrates the finding of this study are appropriate in light of the way that major share of tested respondents is very much familiar with mobile banking facility in financial transactions and able to explain their perspective (emotions) better amid questionnaires filling.

\section{Reliability and Validity Test}

Reliability characterized as a scale that specifies, how free is the information from random error. One approach to test reliability is by surveying through inward consistency. Internal consistency is how much the items that make up the scale are for the most part estimating the equivalent attributes (Pallant, 2007). The most regularly utilized measurement to test reliability quality is Cronbach's alpha coefficient, which offers some benefit from 0 to 1 , with the high esteem demonstrating more noteworthy reliability. Sekaran (2009) referenced that Cronbach's alpha is quality coefficient that shows how well the items are emphatically correlated to each other. The reliability experiment must be led in this exploration to see the level of quality of every variable. Hence, the processes of all variables in this research were satisfactory since Cronbach's alpha is above 0.6 . Table 1.3 demonstrates the reliability of reliability of all which extend 0.728 to 0.860 .

\begin{tabular}{lll}
\hline Variables & N of Items & Cronbach's alpha \\
\hline Optimism & 4 & 0.737 \\
Innovativeness & 4 & 0.805 \\
Discomfort & 4 & 0.728 \\
Insecurity & 4 & 0.799 \\
User satisfaction & 4 & 0.860 \\
Intention to use mobile & 4 & 0.806 \\
banking & & \\
\hline
\end{tabular}

\section{Table 1.3: Reliability test of Variables}

\section{Descriptive Analysis of the Variables}

This segment clarifies calculation of an arrangement of descriptive tests. This is reason that it depicts every one of the characteristics of an arrangement of dissemination scores. It enables an analyst to look at the study rapidly so as to effectively get the data of the research. For this situation, it was utilized in this part to improve simple comprehension and interpretation of the data contain thus. The following is the table showing the synopsis of the descriptive measurements for independent factors; optimism, innovativeness, discomfort, insecurity, perceived usefulness (mediator) and intention to use mobile banking as dependent variable. 


\begin{tabular}{|c|c|c|c|}
\hline Variables & $\mathbf{N}$ & Mean & Std. Deviation \\
\hline Optimism & 410 & 3.9551 & 0.63335 \\
\hline Innovativeness & 410 & 4.1233 & 0.58462 \\
\hline Discomfort & 410 & 3.5524 & 0.61269 \\
\hline Insecurity & 410 & 4.2217 & 0.54521 \\
\hline User satisfaction & 410 & 3.8174 & 0.62628 \\
\hline $\begin{array}{l}\text { Intention to } \\
\text { mobile banking }\end{array}$ & 410 & 4.0991 & 0.64349 \\
\hline
\end{tabular}

Table 1.4: Descriptive Measures $(\mathrm{N}=\mathbf{4 1 0})$

The outcome demonstrates that mean for insecurity 4.2217 shows most noteworthy set apart by respondents, with least standard deviation 0.54521 . That implies the investigation sees insecurity have extremely critical in affecting choosing mobile banking. Next, discomfort has the most minimal mean 3.5524 with exclusive standard deviation 0.61629 as contrast with innovativeness $(\mathrm{M}=4.1233, \mathrm{SD}=0.5846)$. It demonstrates that mobile banking is more appealing to respondents. Also perceived usefulness level seen by respondents is taken mean 3.3.8174 and standard deviation 0.62628. At long last, it portrays that all qualities are not quite the same as one respondent to another. These outcomes the satisfactory fluctuation in reactions.

\section{Testing of Research Hypotheses}

The reception of Pearson relationship was educated by what scholars like Sekaran (2009). Pearson Correlation is appropriate for the investigation of associations among factors. This area of the section estimated the force and direction of the straight connection optimism, innovativeness, discomfort, insecurity, user satisfaction (mediator) and intention to use mobile banking. The scopes of the relationship coefficient are -1 (negative relationship) to +1 (positive relationship).

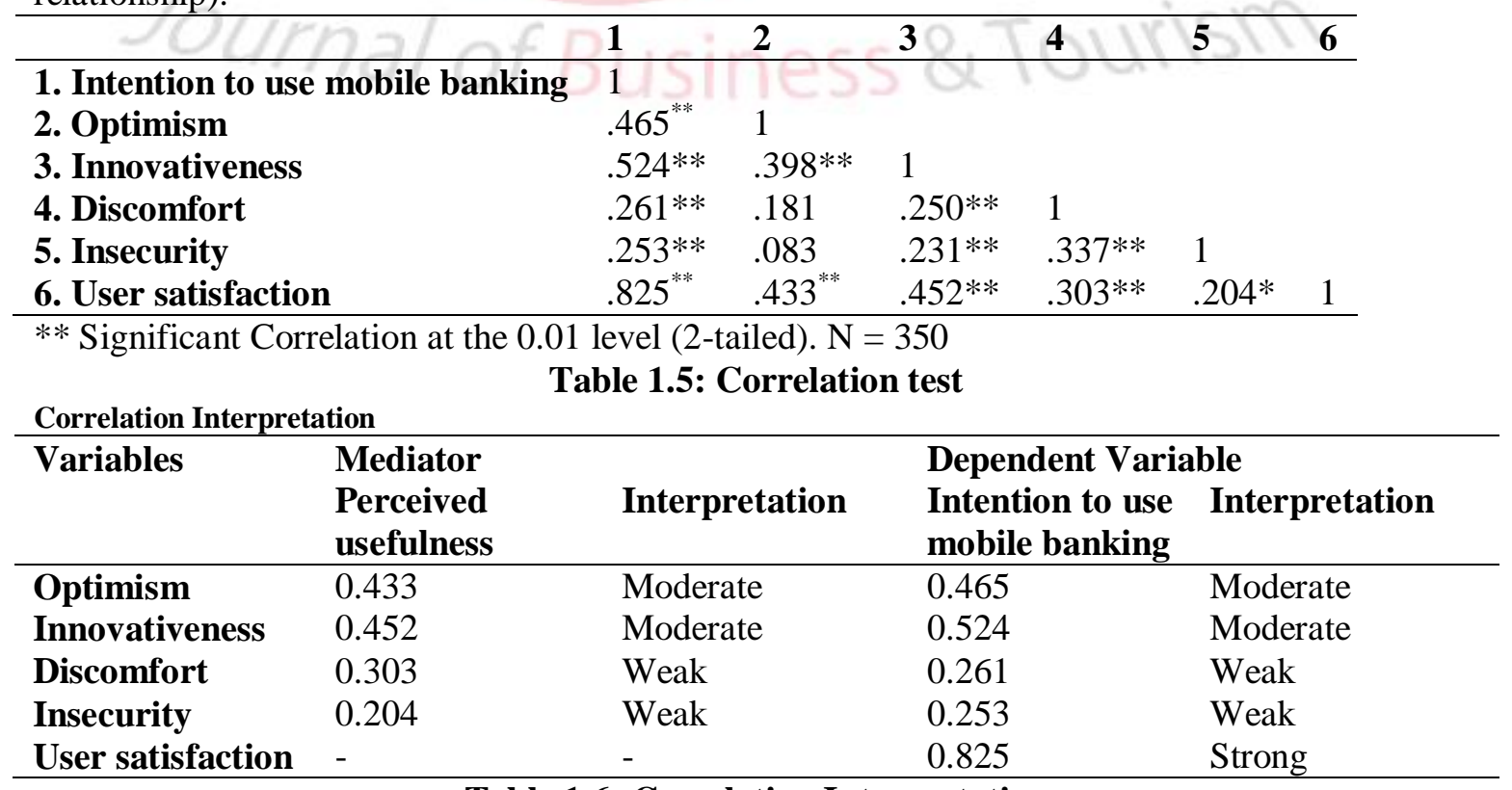

Table 1.6: Correlation Interpretation 
Table 1.6 above demonstrates the strength between variables of the proposed of model. The strength of the relationship of optimism and innovativeness, at $(r=0.433$ and $r=0.452$ respectively) in the direction to user satisfaction are moderate, with correlation range between $0.41-0.70$. Similarly, the other two variables discomfort and insecurity demonstrates feeble connection (at $r=0.303$ and $r=0.204$, respectively) towards user satisfaction, which keeps of correlation in the scope of $0.21-0.40$. Amongst all four factors, insecurity is the weakest relationship towards user satisfaction. On the other hand, the Table 1.6 also demonstrates the strength between independent and dependent factors. Among the four independent variables insecurity still the weakest connection, where the value $r=0.253$ shows weak connection towards a goal to utilize mobile banking. Furthermore, discomfort (where, $r=0.261$ ) likewise demonstrate a weak connection to mobile banking appealing to use. Conversely, optimism and innovativeness (where, $r=0.524$ and $r=0.465$ ) respectively, both flag a moderate relationship toward intention to use mobile banking. Additionally, user satisfaction demonstrates the strongest connection against the intention to use mobile banking, at $r=0.825$.

\section{Multiple Regression Analysis (Hypothesis Testing)}

As per Pallant (2007), Beta numbers under standardized coefficient sections clarified the commitment of every independent factor toward the perceived usefulness. The most noteworthy estimation of Beta showed the solid, one of a kind commitment in clarifying the mediator factors when the variance clarified by every other variable as demonstrated is controlled for.

\begin{tabular}{llllll}
\hline Model & \multicolumn{2}{l}{ Unstandardized Coefficient } & $\begin{array}{l}\text { Standardized } \\
\text { Coefficient } \\
\text { Beta }\end{array}$ & T & Sig. \\
& B & Std. Error & & & \\
\hline (Constant) & 0.537 & 0.049 & & 5.751 & 0.000 \\
OPT & .379 & .093 & .323 & 32.468 & 0.000 \\
INN & .247 & .071 & .254 & .526 & 0.022 \\
DIS & .196 & .085 & .159 & 1.273 & 0.142 \\
INS & .052 & .093 & .041 & 0.061 & 0.304 \\
\hline
\end{tabular}

a. Dependent Variable: User Satisfaction (US)

Table 1.7 Report of Coefficients (IV with MV)

Optimism has a constructive effect on a client's perceived usefulness of portable banking. In this way, hypothesis 1 is acknowledged and accepted. The expansion in innovativeness level in client will likewise build the perceived usefulness of moveable banking. In this manner, hypothesis 2 is also acknowledged and accepted. Since the hypothesis of this examination expressed that discomfort or uneasiness adverse effects a client's satisfaction of versatile mobile banking; along these lines hypothesis 3 is rejected. Nonetheless, since the hypothesis of this exploration expressed that insecurity negatively affects a client's satisfaction of portable use of banking (mobile banking), consequently hypothesis 4 is also rejected.

\begin{tabular}{|c|c|c|c|c|c|}
\hline \multirow[t]{2}{*}{ Model } & \multicolumn{2}{|c|}{ Unstandardized Coefficient } & \multirow{2}{*}{$\begin{array}{l}\text { Standardized } \\
\text { Coefficient } \\
\text { Beta }\end{array}$} & \multirow[t]{2}{*}{$\mathbf{T}$} & \multirow[t]{2}{*}{ Sig. } \\
\hline & B & Std. Error & & & \\
\hline (Constant) & 2.447 & 0.779 & & 43.715 & 0.000 \\
\hline $\begin{array}{l}\text { User } \\
\text { Sation }\end{array}$ & .861 & .037 & .825 & 59.402 & 0.000 \\
\hline
\end{tabular}

a. Dependent Variable: Intention to use mobile banking (ITUMB)

Table 1.8: Report of Coefficients (MV with DV) 
In table 1.8 the Beta estimation of perceived usefulness is 0.825 which shows the beneficial outcome towards client's aim to utilize mobile banking. This outcome likewise can be translated as the more clients saw mobile banking as a valuable technology; the higher was the goal to utilize it. In this way, hypothesis 5 is also acknowledged and accepted.

Hierarchical regression analysis: Mediation Testing

To assess the distinctive impacts of a scope of independent variables, the research model is structured hierarchically. This regression analysis allows an assessment of the extra impacts of the independent variables, which are placed in each stage of the analysis. Baron and Kenny (1986) proposed that a mediator can be acknowledged when it fulfills four conditions: First, the independent variables (i.e. optimism, innovativeness, discomfort, insecurity) should correspond with the hypothesized assumed mediator user satisfaction. Secondly, the independent variables must connect with dependent variable intention to use mobile banking. Thirdly, the mediator between must correlate with the dependent variable which is intention to use mobile banking. Fourth and finally, a formerly significant impact of predictor variables is diminished to nonsignificant or diminished as far as impact size after the incorporation of mediator variables into the analysis. In this regression result, standardized coefficients (standardized beta) were adopted for all analyses (Jaccard et al., 1990). Table 1.9 shows the summary of coefficients between IVs toward Intention to Use mobile banking (DV).

Table 1.9: Report of Coefficients (IV with DV)

\begin{tabular}{|c|c|c|c|}
\hline \multirow{3}{*}{ Model } & \multirow{2}{*}{\multicolumn{2}{|c|}{ Unstandardized Coefficient }} & \multirow{3}{*}{$\begin{array}{l}\text { Standardized } \\
\text { Coefficient } \\
\text { Beta }\end{array}$} \\
\hline & & & \\
\hline & B & Std. Error & \\
\hline (Constant)User & 2.447 & .779 & \\
\hline satisfaction & .861 & .037 & \\
\hline & & & .825 \\
\hline (Constant) & -.273 & 1.2414 & \\
\hline User satisfaction & .773 & $.054 \mathrm{~S}$ & .707 \\
\hline Optimism & .121 & .057 & .089 \\
\hline Innovativeness & .148 & .055 & .137 \\
\hline Discomfort & -.036 & .062 & -.027 \\
\hline Insecurity & .088 & .058 & 然8 \\
\hline
\end{tabular}

a. Dependent Variable: ITUMB

Mediating effect of user satisfaction on relationship of optimism and intention to use mobile banking.

The below Table 1.10 demonstrates the regression effect for three factors containing Optimism, user satisfaction, and Intention to Use mobile banking.

\section{Standardized Regression \\ Coefficient ( $\beta$ )}

Optimism $\Rightarrow$ User satisfaction(Path a) 0.313

User satisfaction Intention to Use (Path b) 0.825

Optimism $\Rightarrow$ Intention to Use Mobile Banking (Path c) 0.089

Table 1.10: Regression Results OPT, US, AND ITUMB 
The path test from the Table 1.10 can be pictured as in Figure 1.3. In this investigation, it very well may be anticipated whether the Optimism (OPT) impact directly or indirectly way on the Intention to Use Mobile Banking (ITUMB), by affecting User satisfaction (US) as a mediator.

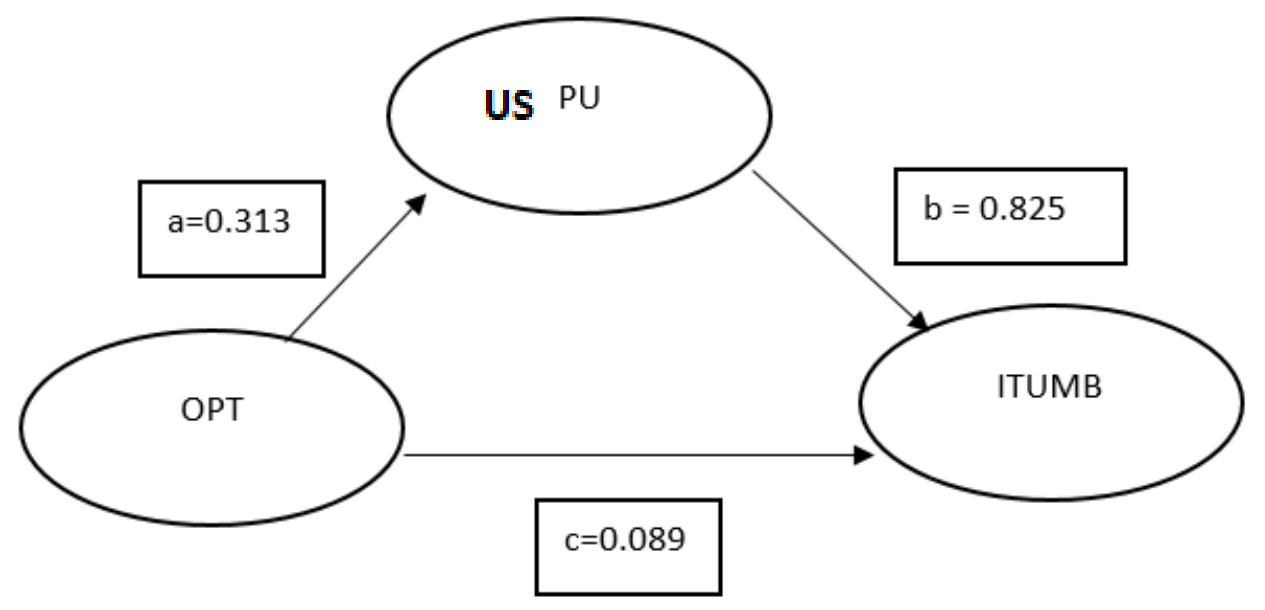

Figure 1.3: Path test of Mediation Effect of Optimism and Intention to Use Mobile Banking Along these lines, the figuring beneath shows the estimation of indirect impact for this relationship:

$\mathrm{C}^{\prime}=\mathrm{a} * \mathrm{~b}$

Whereby:

$C^{\prime}$ is implicit effect or the intermediation effect (Baron and Kenny, 1986)

$a=\beta$ value for path a

$b=\beta$ value for path $b$

$C^{\prime}=(0.313)(0.825)$

$\mathrm{C}^{\prime}=0.258$

As per the first estimation, the value of indirect impact $\left(\mathrm{C}^{\prime}\right)$ is 0.258 , which is in excess of an immediate impact on the value of $c=0.089$. As indicated by Baron and Kenny (1986), if $C^{\prime}=0$ or $\mathrm{C}^{\prime}>\mathrm{c}$, it implies that it is a full mediation, and if $\mathrm{C}^{\prime}<\mathrm{c}$, it implies that it is a halfway mediation. Thusly, it tends to be distinguished that perceived usefulness is a full mediation of optimism and intention to use mobile banking in view of the estimation of $\mathrm{C}^{\prime}>\mathrm{c}$, which is 0.258 is more noteworthy than 0.089 .

Mediating effect of user satisfaction on relationship of innovativeness and intention to use mobile banking.

The below Table 1.11 demonstrates the regression effect for three factors containing innovativeness, user satisfaction, and Intention to Use mobile banking.

\section{Standardized Regression}

Coefficient ( $\beta$ )

/Innovativeness $\quad$ User Satisfaction (Path a) 0.254

/user satisfaction Intention to Use (Path b) 0.825

/Innovativeness $\quad$ Intention to Use Mobile Banking (Path c) 0.137

Table 1.11: Regression Results INN, PU, AND ITUMB 
The path test from the Table 1.11 can be pictured as in Figure 1.4. In this investigation, it very well may be anticipated whether the Innovativeness (INN) impact directly or indirectly way on the Intention to Use Mobile Banking (ITUMB), by affecting user satisfaction (US) as a mediator.

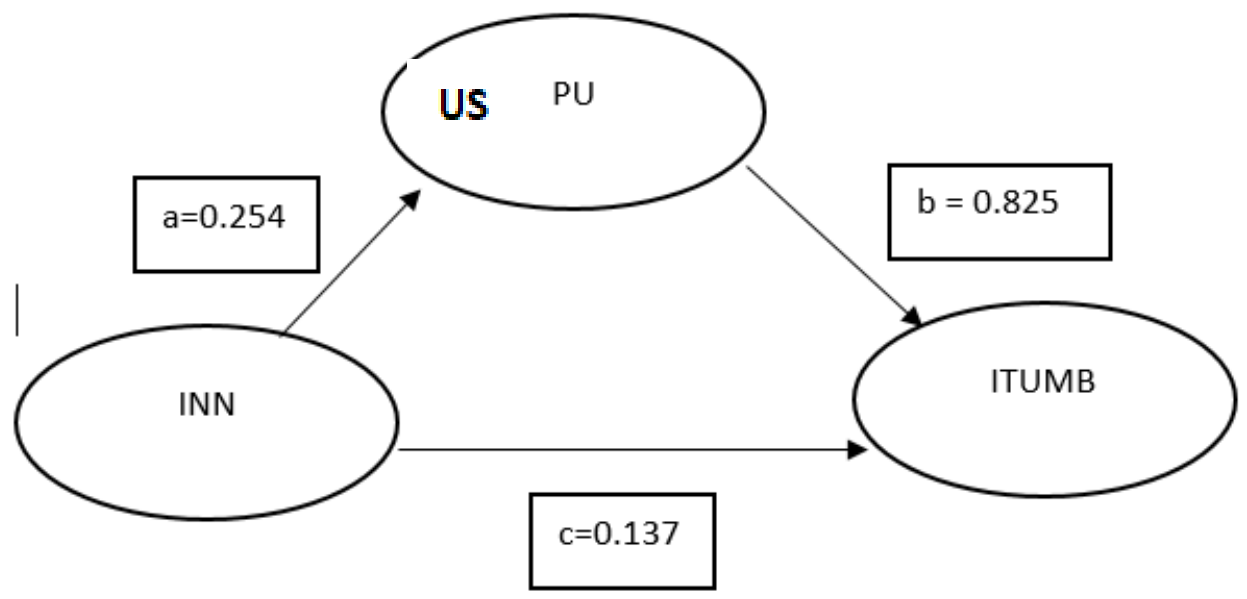

Figure 1.4 Path test of Mediation Effect of Innovativeness and Intention to Use Mobile Banking Along these lines, the figuring beneath shows the estimation of indirect impact for this relationship:

$\mathrm{C}^{\prime}=\mathrm{a} * \mathrm{~b}$

Whereby:

$\mathrm{C}^{\prime}$ is implicit effect or the intermediation effect (Baron and Kenny, 1986)

$\mathrm{a}=\beta$ value for path a

$\mathrm{b}=\beta$ value for path $\mathrm{b}$

$C^{\prime}=(0.254)(0.825)$

$\mathrm{C}^{\prime}=0.2095$

As per the first estimation, the value of indirect impact $\left(C^{\prime}\right)$ is 0.2095 , which is in excess of an immediate impact on the value of $c=0.0137$, as indicated by Baron and Kenny (1986), if $C^{\prime}=0$ or $\mathrm{C}^{\prime}>\mathrm{c}$, it implies that it is a full mediation, and if $\mathrm{C}^{\prime}<\mathrm{c}$, it implies that it is a halfway mediation. Thusly, it tends to be distinguished that user satisfaction is a full mediation of innovativeness and intention to use mobile banking in view of the estimation of $\mathrm{C}^{\prime}>\mathrm{c}$, which is 0.2095 is more noteworthy than 0.137 .

Mediating effect of user satisfaction on relationship of discomfort and intention to use mobile banking.

The below Table 1.12demonstrates the regression effect for three factors containing discomfort, user satisfaction, and Intention to Use mobile banking.

\section{Standardized Regression \\ Coefficient ( $\beta$ )}

\begin{tabular}{lll}
\hline /Discomfort & User satisfaction (Path a) & 0.168 \\
/User satisfaction Intention to Use (Path b) & 0.825 \\
/Discomfort $\quad$ Intention to Use Mobile Banking (Path c) & -0.27
\end{tabular}

Table 1.12 Regression Results DIS, US, AND ITUMB 
The path test from the Table 1.12 can be pictured as in Figure 1.5. In this investigation, it very well may be anticipated whether the Discomfort (DIS) impact directly or indirectly way on the Intention to Use Mobile Banking (ITUMB), by affecting User satisfaction (US) as a mediator.

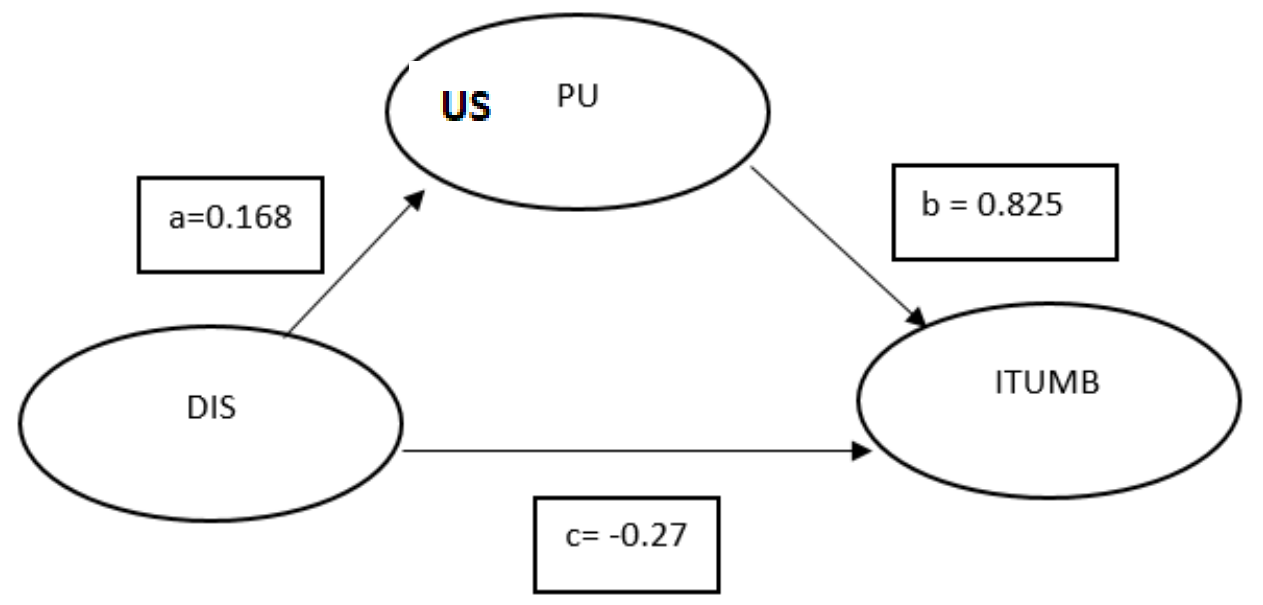

Figure 4.3: Path test of Mediation Effect of Discomfort and Intention to Use Mobile Banking Along these lines, the figuring beneath shows the estimation of indirect impact for this relationship:

$\mathrm{C}^{\prime}=\mathrm{a} * \mathrm{~b}$

Whereby:

$\mathrm{C}^{\prime}$ is implicit effect or the intermediation effect (Baron and Kenny, 1986)

$a=\beta$ value for path $a$

$\mathrm{b}=\beta$ value for path $\mathrm{b}$

$C^{\prime}=(0.168)(0.825)$

$\mathrm{C}^{\prime}=0.1386$

As per the first estimation, the value of indirect impact $\left(\mathrm{C}^{\prime}\right)$ is 0.1386 , which is in excess of an immediate impact on the value of $c=-0.027$, as indicated by Baron and Kenny (1986), if $C^{\prime}=0$ or $\mathrm{C}^{\prime}>\mathrm{c}$, it implies that it is a full mediation, and if $\mathrm{C}^{\prime}<\mathrm{c}$, it implies that it is a partial mediation. Thusly, it tends to be distinguished that user satisfaction is a full mediation of discomfort and intention to use mobile banking in view of the estimation of $\mathrm{C}^{\prime}>\mathrm{c}$, which is 0.1386 is more noteworthy than 0.027 .

Mediating effect of user satisfaction on relationship of insecurity and intention to use mobile banking.

The below Table 1.13 demonstrates the regression effect for three factors containing Insecurity, user satisfaction, and Intention to Use mobile banking.

\section{Standardized Regression}

\section{Coefficient ( $\beta$ )}

\begin{tabular}{lll}
\hline /Insecurity user satisfaction (Path a) & 0.047 \\
/ user satisfaction Intention to Use (Path b) & 0.825 \\
/Insecurity Intention to Use Mobile Banking (Path c) & 0.068
\end{tabular}

Regression Results INS, US, AND ITUMB 
The path test from the Table 1.13 can be pictured as in Figure 1.5. In this investigation, it very well may be anticipated whether the Insecurity (INS) impact directly or indirectly way on the Intention to Use Mobile Banking (ITUMB), by affecting user satisfaction (US) as a mediator.

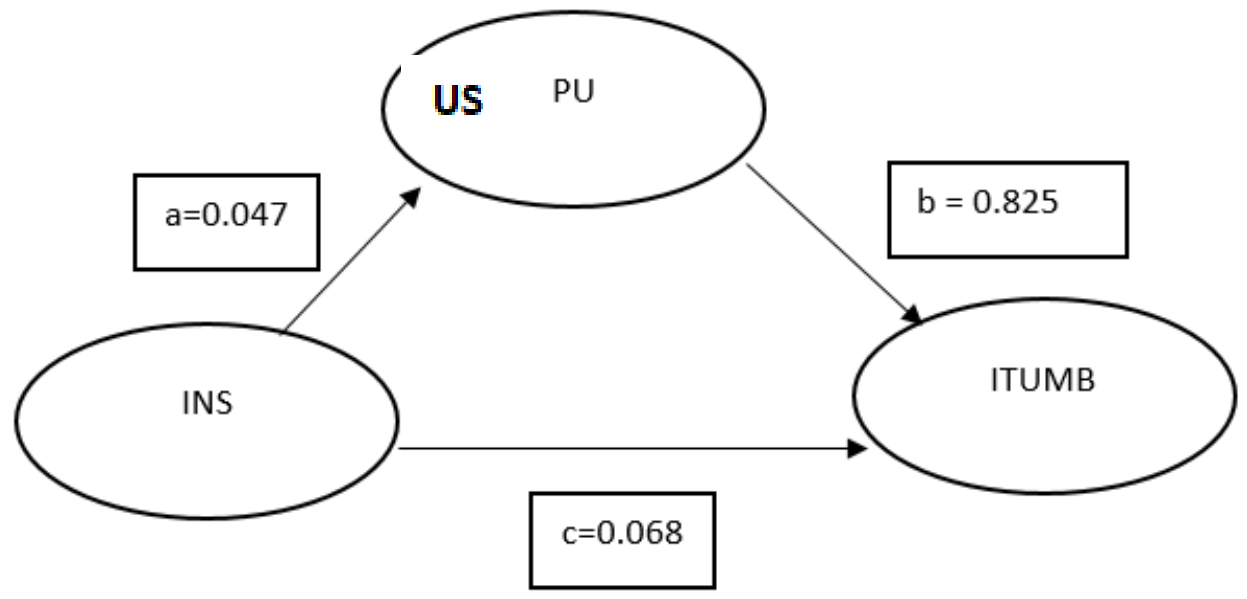

Figure 1.5: Path test of Mediation Effect of Insecurity and Intention to Use Mobile Banking Along these lines, the figuring beneath shows the estimation of indirect impact for this relationship:

$\mathrm{C}^{\prime}=\mathrm{a}$ *b Whereby:

$C^{\prime}$ is implicit effect or the intermediation effect (Baron and Kenny, 1986)

$\mathrm{a}=\beta$ value for path a

$\mathrm{b}=\beta$ value for path $\mathrm{b}$

$C^{\prime}=(0.047)(0.825)$

$C^{\prime}=0.0387$

As per the first estimation, the value of indirect impact $\left(\mathrm{C}^{\prime}\right)$ is 0.0387 , which is in excess of an immediate impact on the value of $c=0.068$, as indicated by Baron and Kenny (1986), if $C^{\prime}=0$ or $\mathrm{C}^{\prime}>\mathrm{c}$, it implies that it is a full mediation, and if $\mathrm{C}^{\prime}<\mathrm{c}$, it implies that it is a partial mediation. Thusly, it tends to be distinguished that user satisfaction is a full mediation of insecurity and intention to use mobile banking in view of the estimation of $\mathrm{C}^{\prime}>\mathrm{c}$, which is 0.0387 is more noteworthy than 0.068 .

\section{Summary of the Findings}

In this research, there are assortments of the hypothesis result that recognized and inspected by researcher. As indicated by the consequence of multiple regression analysis, linear regression investigation and hierarchical regression investigation, the researcher distinguished that there are four hypotheses were acknowledged or accepted and have a noteworthiness impact between independent, mediating, and dependent variables. Be that as it may, the other one hypothesis in this research exploration is rejected. The accompanying table 1.14 presents that the hypothesis result that investigated and analyzed by researcher: 


\begin{tabular}{|c|c|}
\hline Hypothesis & Accepted/ Rejected \\
\hline $\begin{array}{l}\mathbf{H}_{1} \text { : There is (positive) relationship between } \\
\text { optimism and user satisfaction. }\end{array}$ & Accepted \\
\hline $\begin{array}{l}\mathbf{H}_{2:} \text { There is (positive) relationship between } \\
\text { Innovativeness and user satisfaction. }\end{array}$ & Accepted \\
\hline $\begin{array}{l}\mathbf{H}_{3}: \text { There is (negative) relationship of } \\
\text { discomfort with user satisfaction. }\end{array}$ & Rejected \\
\hline $\begin{array}{l}\mathbf{H}_{4}: \text { There is (negative) relationship of } \\
\text { insecurity with user satisfaction. }\end{array}$ & Rejected \\
\hline $\begin{array}{l}\text { H5: The relationship between optimism, } \\
\text { innovativeness, discomfort, insecurity and } \\
\text { intention to use mobile banking which is } \\
\text { mediated by user satisfaction. }\end{array}$ & Accepted \\
\hline
\end{tabular}

\section{Discussions}

Despite the fact that mobile banking in Pakistan is moderately new, it is still at the propelled stage contrasted with the Internet banking, which left much opportunity to get better. In view of the findings demonstrate that the mobile banking is gradually making up for internet banking as lot of consumers are getting to be aware of the product and services. Consequently, there is a need to comprehend the extent of wave of mobile banking by the consumers and to analyze the elements influencing the expectation to utilize mobile banking. However, the model was produced in this study towards accomplishing better use of the mobile banking in the future.

The factor of technology readiness which are indulge in this study optimism (OPT), innovativeness (INN), discomfort (DIS) and insecurity (INS) toward the user satisfaction, the study received the Descriptive Analysis, Correlation Analysis and Multiple Regression Analysis to translate and give a superior comprehension of the issues. In light of this findings, optimism and innovativeness demonstrate a moderate quality of relationship towards user satisfaction. While the two factors, discomfort and insecurity, represent weak connection towards the perceived usefulness of mobile banking. Numerous Regression Analysis additionally shows the positive and negative impact of the relationship. Optimism and innovativeness show a beneficial outcome toward user satisfaction of banking mobile. This outcome can be translated as when the optimism dimension of consumers' expands, their view with respect to the usefulness of the mobile banking will positively build, consequently, affecting them to utilize the technology (Srivastava, 2018).

In view of the review led, the majority of the respondents concur that mobile banking empowers them to finish the banking exercises helpfully and productively while remaining respondents trust that mobile banking will enhance their performance in leading bank transactions. Along these lines in this study, perceived usefulness is a powerful and close predecessor of aim to utilize mobile banking. Other than that, user satisfaction is likewise a full mediator between to every factor, with the exception of insecurity. The user satisfaction just has partial mediation on the connection among insecurity and the intention to utilize mobile banking.

\section{Limitations}

This exploration probably won't have the capacity to sum up the conclusion of all client base. Other than that, this study consider just spotlights on the factors of technology readiness which optimism, innovativeness, discomfort and insecurity and perceived usefulness. Moreover, there are numerous different factors, for example, trust or self-viability that likewise can impact the 
customer's aim to utilize mobile banking. Along these lines, the future research should investigate and think about different factors for better research in versatile mobile banking. In addition, this study just confines its target populace of Punjab and the sample was taken from banks only because of the area and time limitation. The outcomes acquired from this research may less be generalizable contrasted with the expansive sample utilized. Indeed, even with these impediments, the present research can be used as a pilot study to investigate bank clients' behavioral intention to utilize mobile banking. The research will have the capacity to include to the information accessible on mobile banking studies in Pakistan.

\section{Recommendation}

Thefuture research will be related other than the Punjab and test the findings with a quantitative methodology. It would likewise be fascinating to consider this research issue in different societies to find any distinctions in qualities and conclusions, therefore inevitably to have the capacity to sum up the results of this research.Future research focus on antecedents of technological readiness, quality of technology and compatibility examine the customer's involvement to use the mobile banking.Further the study can be focus on paradigms suitable for mobile banking which are useful for monetary transactions. It also carries out empirical and conceptual work to measure the services quality,perceived usefulness and user satisfaction with mobile banking. Hence, it also determines various characteristics of the adopters as well as non-adopters of mobile services. Build trust is another aspect through high the vulnerability of wireless network. Future research ought to consider utilizing diverse Likert scale, as in this study the vast majority of the respondents would in general pick neutral as an answer which caused trouble in soliciting the genuine answer from those studied.

\section{Conclusion}

As overall study proposed that two technology readiness elements have a positive and significant impact, either specifically or by implication, on the choice of intention to use mobile banking. Aside from these, two other technology readiness components were insignificant in this study. Probably, this study is restricted as use of small sample test and model depended on the limited banks. This study utilized users of mobile application to use banking transaction, it may intrigue test if other individuals have varying perspectives as to their organizations' availability to implement this technology.

Discomfort shows to buyers' tensions when confronting innovate(Tesar, 2007). Guhr et al. (2013) additionally contend that discomfort appearances to the degree to which individuals have a general tension while receiving innovation based product or service. This uneasiness and anxiety inclination when utilizing innovation may repulse the client in embracing the technology. Along these lines, in this study, it is demonstrated that when the clients have an inclination discomfort while utilizing mobile banking, they are hesitant to utilize the technology.

Though insecurity variable spreads situations where the shopper does not trust a technological item and questions that item will satisfy its task (Cascio and Montealegre, 2016). Despite the fact that to some degree identified with the discomfort variable, this dimension varies from it in that it centers around explicit parts of technology based or as opposed to with respect to an absence of comfort with technology all in all (Parasuraman and Colby, 2015). In this manner, in this study, it very well may be reasoned that when clients don't trust or feel shaky about utilizing new innovation, they move in an opposite direction from endeavoring to utilize the technology (Broeders and Khanna, 205). As an end, high insecurity and discomfort with innovation prompts bring down deceptive user satisfaction of mobile banking (Barati and Mohammadi, 2009). 
In addition, while our results offer beginning bits of knowledge, they ought to be checked with service classes other than assurance based ones. The web benefit arrangements industry is a moderately novel setting, and keeping in mind that our examination yields intriguing results. It additionally opens the way to other scholars to think about the connections in other industries. Estimating the job of technology readiness plays in B2B innovation appropriation crosswise over different fields, expanding on the surviving Innovation Adoption Model structure and its expansions, could likewise yield important outcomes.As an end, technology readiness factors including; optimism, innovativeness, insecurity and discomfort do contribute in the investigation of the intention to utilize mobile banking. The coordinated model of technology readiness and acceptance provides a superior result in understanding the client's adoption level, particularly in the new technology.

\section{Reference}

Aboelmaged, M., \& R. Gebba, T. (2013). Mobile Banking Adoption: An Examination of Technology Acceptance Model and Theory of Planned Behavior. International Journal of Business Research and Development, 2(1), 35-50.

Al-Jabri, I. \& Sohail, M. (2016). Mobile Banking Adoption: Application of Diffusion of Innovation Theory. Journal Of Electronic Commerce Research, 13(4), 379-391.

Ambler, T., \& Barrow, S. (1996). The employer brand. Journal of brand management, 4(3), 185206.

Amin, H., Supinah, R., Aris, M. M., \& Baba, R. (2012). Receptiveness of mobile banking by Malaysian local customers in Sabah: an empirical investigation. Journal of internet banking and commerce, $17(1), 1$.

Aybay, G., Sindhu, P. \& Venkatramani, A.(2018). Juniper Networks Inc. Methods and apparatus for configuring a virtual network switch. U.S. Patent 9,882,776.

Amit, R., \& Schoemaker, P. J. (1993). Strategic assets and organizational rent. Strategic management journal, 14(1), 33-46.

Bandura, A., Barbaranelli, C., Caprara, G. V., \& Pastorelli, C. (2001). Self-efficacy beliefs as shapers of children's aspirations and career trajectories. Child development, 72(1), 187-206.

Barati, S., \& Mohammadi, S. (2009). An efficient model to improve customer acceptance of mobile banking. In World Congress on Engineering and Computer Science (Vol. 2, pp. 20-22).

Barclay, C. (2014). Using frugal innovations to support cybercrime legislations in small developing states: introducing the cyber-legislation development and implementation process model (CyberLeg-DPM). Information Technology for Development, 20(2), 165-195.

Baron, R. M., \& Kenny, D. A. (1986). The moderator-mediator variable distinction in social psychological research: Conceptual, strategic, and statistical considerations. Journal of personality and social psychology, 51(6), 1173.

Barquin, S., \& Vinayak, H. V. (2015). Digital Banking in Asia: What do consumers really want. McKinsey \& Company, 1-12.

Başgöze, P. (2015). Integration Of Technology Readiness (Tr) Into The Technology Acceptance Model (Tam) For M-Shopping. International Journal Of Scientific Research And Innovative Technology, 2(3), 26-35.

Basheer, L., Kropp, J., \& Cleland, D. J. (2001). Assessment of the durability of concrete from its permeation properties: a review. Construction and building materials, 15(2-3), 93-103.

Bold, C. (2011). Branchless banking in pakistan: A laboratory for innovation. 
Broeders, H., \& Khanna, S. (2015). Strategic choices for banks in the digital age. McKinsey \& Company.

Cascio, W. F., \& Montealegre, R. (2016). How technology is changing work and organizations. Annual Review of Organizational Psychology and Organizational Behavior, 3, 349-375.

Chen, S., Chen, H., \& Chen, M. (2009). Determinants Of Satisfaction And Continuance Intention Towards Self-Service Technologies. Industry Mgmt. \& Data Systems, 109(9), 1248-1263.

Chowdhary, R. K. (2017). Universal Banking Concept and its Awareness. Journal of Bank Management \& Financial Strategies, 1(1), 10-14.

Darroch, J. E. (2013). Trends in contraceptive use. Contraception, 87(3), 259-263.

Davis, F. D. (1989). Perceived Usefulness, Perceived Ease Of Use, And User Acceptance Of Information Technology. MIS Quarterly, Vol. 13, No. 3.Pp. 319-340

Demirci, A. E., \& Ersoy, N. F. (2008). Technology readiness for innovative high-tech products: how consumers perceive and adopt new technologies. The Business Review, 11(1), 302-308.

Demirci, A. E., \& Ersoy, N. F. (2008). Technology readiness for innovative high-tech products: how consumers perceive and adopt new technologies. The Business Review, 11(1), 302-308.

Draganidis, F., \& Mentzas, G. (2006). Competency based management: a review of systems and approaches. Information management \& computer security, 14(1), 51-64.

Drexelius, K. \& Herzig, M. (2001). Mobile banking and mobile brokerage - Successful

Applications of Mobile Business?. International Management \& Consulting, 16(2), 20-23.

Durodolu, O. O. (2016). Technology acceptance model as a predictor of using information system'to acquire information literacy skills. Library Philosophy and Practice.

Durodolu, O. O. (2016). Technology acceptance model as a predictor of using information system'to acquire information literacy skills. Library Philosophy and Practice.

Edwards, T., Delbridge, R., \& Munday, M. (2005). Understanding innovation in small and medium-sized enterprises: a process manifest. Technovation, 25(10), 1119-1127.

Ensor, B., Montez, T. And Wannemacher, P. (2012), The State Of Mobile Banking 2012,

Forrester Research, Usa Http://Interact.F5.Com/Rs/F5/Images/Forrester\%20report\%20the\%20stat e\%20of\%20mobile\%20banking\%202012.Pdf Assessed (13.10.2018)

Erdoğmuş, N. \& Esen, M. (2011). An Investigation Of The Effects Of Technology Readiness On Technology Acceptance In E-Hrm. Procedia - Social And Behavioral Sciences, 24, 487-495.

Erdoğmuş, N. \& Esen, M. (2011). An Investigation Of The Effects Of Technology Readiness On Technology Acceptance In E-Hrm. Procedia - Social And Behavioral Sciences, 24, 487-495.

Fang, B., Ye, Q., Kucukusta, D., \& Law, R. (2016). Analysis of the perceived value of online tourism reviews: Influence of readability and reviewer characteristics. Tourism Management, 52, 498-506.

Felicia, O. O., \& Ogunnaike, O. O. (2012). GLOBAL ECONOMIC MELTDOWN AND ITS PERCEIVED EFFECTS ON BRANDING OF BANK SERVICES IN NIGERIA. Editorial Note Words from the Board of Editor 2 Profile of Authors Included in this Number 3 Information for Contributors 5, 5(1), 129.

Fishbein, M., \& Ajzen, I. (1974). Attitudes toward objects as predictors of single and multiple behavioral criteria. Psychological Review, 81, 59-74.

Freel, M. S. (2000). Barriers to product innovation in small manufacturing firms. International Small Business Journal, 18(2), 60-80. 
Gerrard, P., Barton Cunningham, J., \& Devlin, J. F. (2006). Why consumers are not using internet banking: a qualitative study. Journal of services Marketing, 20(3), 160-168.

Ghosh, S. (2016). How important is mobile telephony for economic growth? Evidence from MENA countries. info, 18(3), 58-79.

Godoe P. and Johansen, T.S. (2012). Understanding Adoption of New Technologies: Technology Readiness and Technology Acceptance as an Integrated Concept, Journal of European Psychology Students, 3, 38-52.

Godoe, P., \& Johansen, T. (2012). Understanding adoption of new technologies: Technology readiness and technology acceptance as an integrated concept. Journal of European Psychology Students, 3(1).

Green, B. N., \& Johnson, C. D. (2015). Interprofessional collaboration in research, education, and clinical practice: working together for a better future. Journal of Chiropractic Education, 29(1), $1-10$.

Guhr, N., Loi, T., Wiegard, R., \& Breitner, M. (2013). Technology Readiness In Customers' Perception And Acceptance Of Mobile-Payment: An Empirical Study In Finland, Germany, The Usa And Japan. In 11th International Conference on Wirtschaftsinformatik (Pp. 119-133). Leipzig, Germany.

Guhr, N., Loi, T., Wiegard, R., \& Breitner, M. (2013). Technology Readiness In Customers' Perception And Acceptance Of Mobile-Payment: An Empirical Study In Finland, Germany, The Usa And Japan. In 11th International Conference On Wirtschaftsinformatik (Pp. 119-133). Leipzig, Germany.

Guildford JP. Fundamental statistics in psychology and education. New York: McGraw-Hill; 1956.

Hallikainen, H., \& Laukkanen, T. (2016, June). How technology readiness explains acceptance and satisfaction of digital services in B2b healthcare sector? In PACIS (p. 294).

Hernandez, J. S., \& Allen, T. C. (2013). Transformation of pathologists: responding in a volatile, uncertain, complex, and ambiguous environment. Archives of Pathology and Laboratory Medicine, 137(5), 603-605.

Hunter, G.K. and Perreault, W.D. Jr (2007), "Making sales technology effective", Journal of Marketing, Vol. 71 No. 1, pp. 16-34.

Johnson, S. (2014). Competing visions of financial inclusion in Kenya: The rift revealed by mobile money transfer (Bath Papers in International Development and Wellbeing No. 30). Bath: University of Bath, Centre for Development Studies.

Karahanna, E., Straub, D.W. And Chervany, N.L. (1998), "Information Technology Adoption Across Time: A Cross-Sectional Comparison Of Pre-Adoption And Post-Adoption Beliefs", Mis Quarterly, Vol. 23 No. 2, Pp. 183-213.

Khan, I., \& Rashid, N. (2015). Using mobile money to promote financial inclusion in Pakistan. PowerPoint presentation to Karandaaz, Islamabad. Retrieved from https://www.karandaaz.com.pk/wp-content/uploads/2018/07/Using-Mobile-Money-to-PromoteFinancial-Inclusion-in-Pakistan.pdf

Klein, M., \& Mayer, C. (2011). Mobile banking and financial inclusion: The regulatory lessons (Policy Research Working Paper No. 5664). Washington, DC: World Bank.

Kohli, K. (2004). SMS In Banking. Paladion Knowledge Series, Issue January 2004.

Kozinets, R. V. (2007). Technology/ideology: How ideological fields influence consumers' technology narratives. Journal of consumer research, 34(6), 865-881. 
Krejcie, R. V., \& Morgan, D. W. (1970). Determining sample size for research activities. Educational and psychological measurement, 30(3), 607-610.

Lam, S. Y., J. Chiang, and A. Parasuraman. (2008), The Effects of the Dimensions of Technology Readiness on Technology Acceptance: An Empirical Analysis, Journal of Interactive Marketing, 22(4), pp 19-39.

Lam, S. Y., J. Chiang, and A. Parasuraman. (2008), The Effects of the Dimensions of Technology Readiness on Technology Acceptance: An Empirical Analysis, Journal of Interactive Marketing, 22(4), pp 19-39.

Leclercq, A. (2007). The perceptual evaluation of information systems using the construct of user satisfaction: case study of a large French group. ACM SIGMIS Database, 38(2), 27-60.

Lee, H. and Yang, K. (2013), "Interpersonal service quality, self-service technology (SST) service quality and retail patronage", Journal of Retailing and Consumer Service, 20(1), pp. 5157.

Leek, S., \& Christodoulides, G. (2012). A framework of brand value in B2B markets: The contributing role of functional and emotional components. Industrial Marketing Management, 41(1), 106-114.

Liljander, V., Gillberg, F., Gummerus, J. and van Riel, A. (2006), "Technology readiness and the evaluation and adoption of self-service technologies", Journal of Retailing and Consumer Services, 13(3), pp. 177-91

Lin, C., Shih, H., \& Sher, P. (2007). Integrating Technology Readiness Into Technology Acceptance: The Tram Model. Psychology And Marketing, 24(7), 641-657.

Lin, C., Shih, H., \& Sher, P. (2007). Integrating Technology Readiness Into Technology Acceptance: The Tram Model. Psychology And Marketing, 24(7), 641-657.

Lin, J. \& Chang, H. (2011). The Role Of Technology Readiness In Self-Service Technology Acceptance. Managing Service Quality, 21(4), 424-444.

Luppicini, R. (2005). A systems definition of educational technology in society. Educational Technology \& Society, 8(3), 103-109.

Mallat, N., Rossi, M., and Tuunainen, V.K. (2004) Mobile banking services, Communicates of the ACM 47(5) 42-46.

Merritt, C. (2011). Mobile money transfer services: the next phase in the evolution of person-toperson payments. Journal of Payments Strategy \& Systems, 5(2), 143-160.

Meuter, M.L., Bitner, M.J., Ostrom, A.L. and Brown, S.W. (2005), "Choosing among alternative service delivery modes: an investigation of customer trial of self-service technologies", Journal of Marketing, Vol. 69, 61-83.

Meuter, M.L., Bitner, M.J., Ostrom, A.L. and Brown, S.W. (2005), "Choosing among alternative service delivery modes: an investigation of customer trial of self-service technologies", Journal of Marketing, Vol. 69, 61-83.

Mishkin, F., And Eatkins, S. (2008), Financial Markets And Institutions, 6th Ed., Addison Wesley, New York.

Mohd Daud, N., Mohd Kassim, N., Wan Mohd Said, W., \& Mohd Noor, M. (2011). Determining Critical Success Factors Of Mobile Banking Adoption In Malaysia. Australian Journal Of Basic And Applied Sciences, 5(9), 253- 265.

Naumanen, P. (2006). The health promotion of aging workers from the perspective of occupational health professionals. Public Health Nursing, 23(1), 37-45. 
Öfjäll, K., Felsberg, M., \& Robinson, A. (2016, June). Visual autonomous road following by symbiotic online learning. In Intelligent Vehicles Symposium (IV), 2016 IEEE (pp. 136-143). IEEE.

Pachoud, B., \& Corbiere, M. (2014). Practices and interventions related to the work integration of people with a severe mental illness: work outcomes and avenues of research. L'Encephale, 40, S33-44.

Padgett, D. and Mulvey, M.S. (2007), "Differentiation via technology: strategic positioning of services following the introduction of disruptive technology", Journal of Retailing, 83(4), pp. 375-391.

Pallant, J. (2007). SPSS Survival Manual (3rd ed.). Great Britain: Open University Press.

Parasuraman, A. (2000), “Technology Readiness Index (TRI): A Multiple-item Scale to Measure Readiness to Embrace New Tech- nologies,' JournalofService Research, 2 (May), 307-320.

Parasuraman, A. (2000). Technology Readiness Index (Tri): A Multiple-Item Scale to Measure Readiness to Embrace New Technologies. Journal Of Service Research, 2(4), 307-320.

Parasuraman, A., \& Colby, C. (2014). An Updated And Streamlined Technology Readiness Index: Tri 2.0. Journal Of Service Research, 18(1), 59-74.

Parasuraman, A., \& Colby, C. (2014). An Updated And Streamlined Technology Readiness Index: Tri 2.0. Journal Of Service Research, 18(1), 59-74.

Parasuraman, A., \& Colby, C. (2014). An Updated And Streamlined Technology Readiness Index: Tri 2.0. Journal Of Service Research, 18(1), 59-74.

Parasuraman, A., \& Colby, C. L. (2015). An updated and streamlined technology readiness index: TRI 2.0. Journal of service research, 18(1), 59-74.

Piaw, C. Y. (2012). Mastering research methods. Malaysia: McGraw-Hill.

Ramaseshan, B., Kingshott, R., \& Stein, A. (2015). Firm Self-Service Technology Readiness. Journal Of Service Management, 26(5), 751-776.

Rizvi, S. K. A., Naqvi, B., \& Tanveer, F. (2017). Mobile Banking: A Potential Catalyst for Financial Inclusion and Growth in Pakistan.

Rose, J., \& Fogarty, G. J. (2010). Technology readiness and segmentation profile of mature consumers. In Proceedings of the 4th Biennial Conference of the Academy of World Business, Marketing and Management Development (Vol. 4, No. 1, pp. 57-65). Academy of World Business, Marketing and Management Development.

Sakun Boon-Itt , (2015), Managing Self-Service Technology Service Quality To Enhance ESatisfaction, International Journal Of Quality And Service Sciences, 7(4), 373 - 391

Sakun Boon-Itt , (2015), Managing Self-Service Technology Service Quality To Enhance ESatisfaction, International Journal Of Quality And Service Sciences, 7(4), 373 - 391

Sandberg, M. (2013). Case management for frail older people. Effects on healthcare utilisation, cost in relation to utility, and experiences of the intervention (Vol. 2013, No. 97). Lund University, Faculty of Medicine.

Sava, S., Nuissl, E., \& Lustrea, A. (2017). ADULT LEARNING AND EDUCATION: CURRENT EUROPEAN PERSPECTIVES. Researches in Adult Learning and Education: The European Dimension, 6, 3.

Scheier, M. \& Carver, C. (1987). Dispositional Optimism and Physical Well- Being: The Influence of Generalized Outcome Expectancies on Health. J Personality, 55(2), 169-210.

Sekaran U. (2009). Research Methods for Business: A Skills-Building Approach. (6th Ed). New York: John Wiley \& Sons, Inc. 
Sekaran, U. \& Bourgie, R. (2013). Research methods for business. Chichester, West Sussex: Wiley.

Shankar, A., \& Kumari, P. (2016). Factors affecting mobile banking adoption behavior in India. The Journal of Internet Banking and Commerce, 21(1).

Sharma, N. (2015). An Empirical Study On Mobile Banking Technology: Factors Affecting Its Adoption In Indian Context. International Journal Of Computer Science And Technology, 6(1), 53-56.

Sophonthummapharn, K., \& Tesar, G. (2007). Technology Readiness And Propensity Of Cell Phone Users To Subscribe To Commercial Messaging Services. Marketing Management Journal, 17(2), 81-95.

Sophonthummapharn, K., \& Tesar, G. (2007). Technology Readiness And Propensity Of Cell Phone Users To Subscribe To Commercial Messaging Services. Marketing Management Journal, 17(2), 81-95.

Spencer, H. (2011). A matter of trust and identity: Some university teachers' responses to the increased use of information technology in their working environment (Doctoral dissertation, UCL (University College London)).

Storer, M., Hyland, P., Ferrer, M., Santa, R., \& Griffiths, A. (2014). Strategic supply chain management factors influencing agribusiness innovation utilization. The International Journal of Logistics Management, 25(3), 487-521.

Tatevossian, A. R. (2008). Domestic society's (often-neglected) role in nation branding. Place Branding and Public Diplomacy, 4(2), 182-190.

Triki, T., \& Faye, I. (2013). Financial inclusion in Africa. Tunis: African Development Bank. Verhoef, P., Lemon, K., Parasuraman, A., Roggeveen, A., Tsiros, M., \& Schlesinger, L. (2009). Customer Experience Creation: Determinants, Dynamics and Management Strategies. Journal Of Retailing, 85(1), 31-41.

Verhoef, P., Lemon, K., Parasuraman, A., Roggeveen, A., Tsiros, M., \& Schlesinger, L. (2009). Customer Experience Creation: Determinants, Dynamics and Management Strategies. Journal Of Retailing, 85(1), 31-41.

Walczuch, R., Lemmink, J. And Streukens, S. (2007), “The Effect Of Service Employees' Technology Readiness On Technology Acceptance", Information \& Management, 44(2), 206215.

Walczuch, R., Lemmink, J. And Streukens, S. (2007), “The Effect Of Service Employees' Technology Readiness On Technology Acceptance", Information \& Management, 44(2), 206215.

Walton, G., \& Webb, P. (2016). Leading the innovative and creative library workforce: approaches and challenges. In Innovation in Libraries and Information Services (pp. 257-275). Emerald Group Publishing Limited.

Wang, W., Hsieh, P., Butler, J. And Hsu, S.H. (2008), "Innovate With Complex Information Technologies: A Theoretical Model And Empirical Examination", Journal Of Computer Information Systems, 49(1), 27-36.

Wang, Y. S., Lin, H. H., And Luarn, P. (2006). Predicting Consumer Intention To Use Mobile Service. Information Systems Journal, 16(2), 157-179.

Yen, H.R. (2005), "An attribute-based model of quality satisfaction for internet self-service technology", The Service Industries Journal, 25(5), pp. 641-59. 